\title{
THE IMPACT OF FOREIGN INVESTMENT RESTRICTIONS ON THE STOCK RETURNS OF OIL SANDS COMPANIES ${ }^{* \dagger}$
}

\section{Eugene Beaulieu and Matthew M. Saunders}

\section{SUMMARY}

In December 2012, prompted by the proposed purchase of Nexen by the Chinese SOE CNOOC, the federal government announced revised guidelines for investments by state-owned enterprises (SOEs) in the oil sands. Declaring the sale marked "the end of a trend and not the beginning of a trend," Prime Minister Stephen Harper explained how the government would approach such decisions in the future, including placing the onus on foreign investors to demonstrate how deals would be of net benefit to Canada, as well as granting the industry minister the discretion to accept or deny proposed deals.

Accounting for five per cent of Canadian GDP, $\$ 28$ billion in government revenue and three per cent of all jobs nationwide, the oil sands are an integral component of Canada's economy. The sector has long relied on foreign capital to finance projects, meaning that any move to deter outside investment could have profound consequences for the development of this critical economic asset.

In this paper, the authors examine the impact of this policy change by measuring the stock returns of firms operating in the oil sands. Employing an event study analysis, they find empirical evidence that the government's policy change has resulted in the material destruction of shareholder wealth, particularly in the case of the smaller oil companies. What is more, given the composition of the global oil industry has changed to one where SOEs dominate both reserves and production, is this a policy Canada can afford in the long term?

"When we say that Canada is open for business, we do not mean that Canada is for sale to foreign governments."

Prime Minister Stephen Harper, December 7, 2012

"...going forward, the [industry] minister will find the acquisition of control of a Canadian oil-sands business by a state-owned enterprise to be of net benefit, only in an exceptional circumstance."

- Prime Minister Stephen Harper, December 7, 2012

"A year after the new Investment Canada Act rules were announced in December 2012, investment dollars from state-owned enterprises have essentially stopped flowing into the bitumen extraction business. Energy-directed foreign direct investment - of which SOEs play an important role - fell off a cliff in 2013, declining 92 per cent year-to-year from $\$ 27$ billion to $\$ 2$ billion. These are very worrisome statistics for a nation highly dependent on foreign investment to fund its capital-intensive resource industries."

Sebation Gault, December 2, 2013 Published in Alberta Oil Magazine

This research was financially supported by the Government of Canada via a partnership with

Western Economic Diversification.

The authors wish to acknowledge the helpful comments of the anonymous referees. 

QUI EXPLOITENT LES SABLES BITUMINEUX*+

\author{
Eugene Beaulieu et Matthew M. Saunders
}

\title{
RÉSUMÉ
}

En décembre 2012, dans la foulée du projet d'achat de Nexen par la société d'État chinoise CNOOC, le gouvernement fédéral a annoncé des lignes directrices révisées relatives aux investissements des sociétés d'État dans l'exploitation des sables bitumineux. Après avoir déclaré que la vente " ne marque pas le début d'une tendance, mais bien la fin d'une tendance », le Premier ministre Stephen Harper a expliqué la façon dont le gouvernement traiterait dorénavant pareilles décisions : entre autres, il fera reposer sur l'investisseur étranger le fardeau de démontrer qu'une transaction représente un bénéfice net pour le Canada, et il conférera au ministre de l'Industrie le pouvoir discrétionnaire d'accepter ou de refuser les transactions proposées.

L'industrie des sables bitumineux - qui correspond à cinq pour cent du PIB du Canada, à 28 milliards de dollars en recettes publiques et à trois pour cent de tous les emplois à l'échelle nationale - fait partie intégrante de l'économie canadienne. Sachant que ce secteur dépend depuis longtemps des capitaux étrangers pour le financement de ses projets, toute initiative visant à décourager l'investissement étranger pourrait avoir des répercussions profondes sur le développement économique de cet actif économique essentiel.

Dans le présent article, les auteurs examinent les effets de ce changement stratégique en mesurant les rendements boursiers des entreprises qui exploitent les sables bitumineux. À partir de l'analyse d'une étude de cas, données empiriques à l'appui, ils montrent que le changement stratégique du gouvernement a entraîné la destruction matérielle de la valeur actionnariale, en particulier pour les sociétés pétrolières de petite taille. En outre, dans le contexte d'une nouvelle composition de l'industrie pétrolière mondiale où les sociétés d'État dominent les réserves et la production, le Canada a-t-il vraiment les moyens d'appliquer une telle politique à long terme?

"Quand on dit que le Canada est ouvert aux affaires, nous ne voulons pas dire que le Canada est à vendre aux gouvernements étrangers. »

- Stephen Harper, Premier Ministre du Canada, 7 décembre 2012

« À l'avenir, le ministre [de l'Industrie] jugera que l'acquisition du contrôle d'une compagnie canadienne opérant dans les sables bitumineux par une société d'État étrangère sera d'un bénéfice net seulement dans des circonstances exceptionnelles. »

- Stephen Harper, Premier Ministre du Canada, 7 décembre 2012

« Un an après l'annonce des nouvelles règles de la Loi sur Investissement Canada en décembre 2012, les sociétés d'État avaient pratiquement cessé d'investir dans les activités d'extraction des sables bitumineux. Les investissements directs étrangers dans le secteur de l'énergie - où les sociétés d'État jouent un rôle important - ont chuté drastiquement en 2013, passant de 27 à 2 milliards de dollars, soit une baisse de 92 pour cent d'une année sur l'autre. Ces statistiques sont très inquiétantes pour une nation qui dépend fortement des investissements étrangers pour financer ses industries de capital fondées sur les ressources. » [traduction]

- Sebation Gault, 2 décembre 2013, publié dans Alberta Oil Magazine

Cette recherche a été soutenue financièrement en partie par le gouvernement du Canada via Diversification de l'économie de

l'Ouest Canada.

L'auteur tient à remercier les lecteurs critiques anonymes de leurs commentaires pertinents. 


\section{INTRODUCTION}

On December 7, 2012, following the close of markets, Prime Minister Harper announced the approval of the acquisition of the Canadian energy firm Nexen by the Chinese state-owned enterprise (SOE) China National Offshore Oil Corporation (CNOOC). During his press conference, the prime minister announced revised guidelines intended to halt further oil sands acquisitions by SOEs, stating outright that the decision on CNOOC was "the end of a trend and not the beginning of a trend." Specifically, the announcement indicated that, in future, investments by foreign SOEs to acquire control of a Canadian oil sands business would only be approved on an exceptional basis. The industry minister would be responsible for monitoring SOE transactions throughout the economy to determine whether they are of likely net benefit to Canada, and transactions would continue to be reviewed on a case-by-case basis. The purpose of this paper is to examine the impact of this policy change on stock prices of firms operating in the oil sands.

The revised policy guidelines have had their intended effect on SOE investment. In 2013, only a single SOE deal was announced. The deal, which took place outside of the oil sands sector, was worth approximately $\$ 320$ million, considerably less than the $\$ 28$ billion in SOE investment that flowed into Canada in 2012. ${ }^{2}$ According to Jim Prentice, a former industry minister under Prime Minister Harper, Foreign Direct Investment (FDI) into the Canadian energy sector, where SOEs have been major players, "dropped off dramatically" 3 following the announced changes to the Investment Canada Act (ICA). Prentice notes that FDI into the Canadian energy sector declined 92 per cent in 2013 year-to-year from $\$ 27$ billion to \$2 billion. As we discuss below, other sources of investment have failed to materialize in the industry. Although investment declined in the industry following the announced changes to the ICA, there is an important debate on the cause of the decline, and on the impact of the decline in investment on the industry. On the one hand, some observers like Prentice argue that the new rules have contributed to the decline. Others have argued that other challenges in the industry led to the reduction in investment, including higher capital and operating costs, increased environmental regulations, the emergence of other investment options outside of the oil sands and delays in building the infrastructure needed to get the product to the market. According to Grant Ukrainetz from the Korean SOE KNOC, other challenges have contributed to reduced investment in the sector.

I Government of Canada, "Government of Canada Releases Policy Statement and Revised Guidelines for Investments by State-Owned Enterprises," news release, December 7, 2012. http://news.gc.ca/web/articleen.do?crtr.sj1D=\&crtr.mnthndVl=3\&mthd=advSrch\&crtr.dpt1D=\&nid=711489\&crtr.lc1D=\&crtr.tp1D=\&crtr.yrStrtVl= 2008\&crtr.kw=Policy $\% 2 \mathrm{BStatement} \% 2 \mathrm{Band} \% 2 \mathrm{BRevised} \% 2 \mathrm{BGuidelines} \% 2 \mathrm{~B}$ for $\% 2 \mathrm{BInvestments} \% 2 \mathrm{Bby} \% 2 \mathrm{BStateO}$ wned $\% 2 \mathrm{BEnterprises} \& \mathrm{crtr}$. dy StrtVl=26\&crtr.aud1D=\&crtr.mnthStrtVl=2\&crtr.page=1\&crtr.yrndVl=2013\&crtr.dyndVl $=27$ (accessed June 5, 2014)

2 On January 20, 2014, Chinese state-owned Yanchang Petroleum International Limited completed the acquisition of Novus Energy for \$320 million.

3 Prentice, Jim, "Sustaining the Canadian Advantage," Address to the Oil and Money Conference, October 1, 2013. https://www.cibc.com/ca/pdf/investor/prentice-oil-money-london-oct-2013-en.pdf (accessed June 5, 2014). 
"Capital cost pressures in the oil sands have tripled, operating costs in the oil sands at least doubled, we had a change in the oil sands royalty regime, we had greater environmental regulations, costs of compliance have increased, we had continued delays in pipelines that allow us to move products out to maximize revenue, (there is) negative public sentiment toward the oil sands, plus you have the emergence of other opportunities in the U.S. and elsewhere."

Whether, and the extent to which, the changes in the ICA adversely affected the oil sands industry is an empirical question. However, until now, we have relied on anecdotal evidence and there is no empirical evidence on the impact of the policy change on the industry. In this paper, we employ an event study analysis to empirically examine the impact of the 2012 announcement on the stock returns of firms operating in the sector. The advantage of the event study approach is that it allows one to empirically examine the stock market reaction to the regulatory change to assess the degree to which the regulations affected the firms. The analysis is based on the assumption that markets are efficient, and therefore, the impacts of the regulation are capitalized into the share prices and other determinants of the share prices are controlled for in the analysis. This approach is widely used in the finance literature to examine the impact of changes in regulation on firm performance. This is an empirical approach that allows us to control for other factors that may have affected stock returns in the sector.

Although the policy change specifically targets controlling interests by SOEs, it is possible that the new restrictions could have unintended consequences on capital costs and investment in the industry more broadly. We posit that the policy changes could have implications for all forms of financing in the oil sands sector. According to our hypothesis, reducing foreign direct investment, a complementary source of capital, decreases the overall supply of capital to the oil sands sector, and therefore, aggregate capital becomes more expensive. Moreover, there are other peripheral considerations to the revised policy guidelines that potentially make financing more difficult and expensive for oil sands firms. For example, in the capital-intensive oil industry with large fixed and sunk costs, oil sands firms, especially the smaller oil sands firms known as juniors, typically engage in joint ventures (JVs) for their projects. It is possible that the policy changes have impacted this practice even though the intent was to eliminate acquisitions in controlling interests, not JVs. This is because it is commonplace in the event of default in a JV agreement to compensate the non-defaulting party by absorbing the defaulting party's interest in a given project. However, the revised guidelines prohibit acquisitions of control by an SOE in the oil sands sector, unless the circumstances are exceptional. This constraint on a traditional form of compensation due to a default may deter SOEs from entering into JV partnerships with oil sands firms. Although we do not directly examine this channel of the impact of the ICA policy because we do not have data on JV activity, our analysis allows us to directly examine the impact on stock prices. The impact of limiting access to capital will be capitalized into the stock prices of the firms affected. It is likely that the unintended consequences on JVs will impact junior oil sands firms more than the intermediates/seniors. By disentangling the revised guidelines' impact on the juniors and the intermediates/seniors, we are able to examine whether these different types of firms were impacted differently.

\footnotetext{
4 Claudia Cattaneo, "Oil sands investment slowing because of tough market, not new SOE rules, execs say," Financial Post, April 4, 2014. Accessed June 5, 2014 http://business .financialpost.com/2014/04/04/oil-sands-investmentslowing-because-of-tough-market-not-new-soe-rules-execs-say/?_lsa=1d41-0d6e
} 
In particular, using the event study framework, we examine whether the policy change resulted in negative abnormal returns for oil sands firms. We find that the changes to the ICA reduce the stock returns of oil sands companies and that the negative impact was much larger on the juniors. These results are robust to different model specifications and control for other factors that could be affecting the sector. ${ }^{5}$ We argue that the impact of the policy changes, and subsequent reduction in oil sands investment, has increased the cost of capital and the ability of oil sands firms to raise funds. That we find a larger (negative) impact on the oil sands juniors reflects the fact that they are more reliant on external sources of financing due to limited internal cash flow. These results are consistent with our hypothesis that other financing options, such as JVs, have become collateral damage from the changes to the ICA.

This is the first empirical paper to examine the impact of the ICA changes on firms operating in the oil sands. Although we focus on the impact of the policy on share prices, the negative impact has broader implications for the oil sector and the Canadian economy. In the next section we provide a more detailed discussion of the oil sands industry and Canada's foreign investment policy. We point out that the industry requires large amounts of investment beyond what a small capital market like Canada can supply. Canada's historical reliance on foreign investment is particularly acute in the capital-intensive natural resource sector. A policy that limits capital into this sector has historically done damage to the sector and to the Canadian economy. In the concluding section, we attempt to put the recent policy into a broader context. We argue that the broader implications of the policy for the Canadian economy could put employment and social programs at risk as it negatively affects the growth of a sector directly responsible for five per cent of Canada's GDP. We do not, however, measure the impact on real economic variables, such as employment, leaving that instead to future research.

\section{BACKGROUND ON THE OIL SANDS AND INVESTMENT POLICY}

Canada ranks third in the world (after only Venezuela and Saudi Arabia) ${ }^{6}$ in proven oil reserves, with 97 per cent of its 174 billion barrels reserves found in the oil sands. Current oil sands production is approximately 1.7 million barrels per day, ${ }^{7}$ representing a fraction of the total recoverable resource base. Projects in the oil sands are exceptional in three important regards: they have long reserve lives; they are capitally intense with large fixed costs, including significant initial outlays required prior to first production; and, due to economies of scale, they require significant investment to advance to an efficient scale of operations with long-time horizons to realize a return on investment. ${ }^{8}$ Historically, uncertainty has been the greatest deterrent to development in the sector. ${ }^{9}$

5 For more detail on the empirical analysis, including robustness checks, please refer to a longer and more technical version of this paper that is currently available as a working paper: Eugene Beaulieu and Matthew Saunders, "The Impact of Foreign Investment Policy on Stock Returns of Oil Sands Companies," Working Paper 2014-46, Department of Economics, University of Calgary, 2014. http://econ.ucalgary.ca/research/workingpapers/2014/2014-46

6 Source: US Energy Information Agency: http://www.eia.gov/countries/index.cfm?view=reserves

7 Source: Canadian Association of Petroleum Producers: http://www.capp.ca/library/statistics/basic/Pages/default.aspx

8 Paul Chastko, "Anonymity and Ambivalence: The Canadian and American Oil Industries and the Emergence of Continental Oil," The Journal of American History 99 (2012): 166-176.

9 For an explanation of how Canadian government policy has created uncertainty in the country's investment climate, see Chastko, "Anonymity and Ambivalence," 166-176; and Paul Chastko, Developing Alberta's Oil Sands: From Karl Clark to Kyoto (Calgary: University of Calgary Press, 2007). 
The Canadian Energy Research Institute (CERI) forecasts that to achieve full development, oil sands projects will require approximately $\$ 100$ billion in capital investment through $2019 .{ }^{10}$

Prior to the revised guidelines, the trend was one of increasing SOE investment in the oil sands, with Asian acquirers, almost exclusively SOE type entities, as the dominant providers of foreign direct investment. Figure 1 provides an overview of Mergers and Acquisitions (M\&A) activity in the Canadian oil sands from 1999-2014. The figure presents the number and the value of the transactions by year, the price of oil and the share of Asian acquirers in the transactions. Although the share of Asian acquirers does not specifically measure SOE activity, it is safe to infer that the Asia numbers do reflect SOE activity in the sector.

Still, despite the acceleration of SOE investment into the oil sands sector depicted in Figure 1, SOE ownership of the oil sands resource is currently immaterial. According to a recent report by IHS-CERA, total SOE ownership accounted for six per cent of oil sands production in 2012, slightly above the Statistics Canada estimate. ${ }^{l l}$ That same report points out that the United States is the dominant provider of capital to the oil sands, with American citizens controlling 54 per cent of production-weighted ownership and American corporations controlling a further 29 per cent. ${ }^{12}$ Chinese FDI outflows are projected to continue to increase in the short-medium term. According to Dobson, looking just at its global stock of FDI (and there is a great deal of uncertainty about the numbers due to the use of tax havens and platforms in Hong Kong), it is generally accepted that this global stock is somewhere around six per cent of China's GDP and 12th largest in global terms. ${ }^{13}$ It is important to note that China, as measured by flows, was the world's third largest outward investor in 2012, behind Japan and the U.S. The point is that if the stock ratio were to be maintained as the Chinese economy doubles in size by 2020 , its global stock would grow to $\$ 700$ billion, which is similar to those of Canada and Japan today. More bullish estimates put the stock at \$1-2 trillion. Changes to the ICA essentially eliminate this source of capital from investing in controlling interests in the Canadian oil sands.

\footnotetext{
10 Dinara Millington and Carlos A. Murillo, Canadian Oil Sands Supply Costs and Development Projects (2012-2046), Study No. 133, (Calgary: Canadian Energy Research Institute, 2013).

11 IHS CERA, Oil Sands Economic Benefits: Today and in the Future (N.p: IHS CERA, January 2014). http://www.ihs.com/pdfs/OSD-2013-Economic-Benefits-Jan-2-2014.pdf (accessed June 5, 2014)

12 Ibid.

13 Wendy Dobson, China's State-Owned Enterprises and Canada's FDI Policy, SPP Research Papers Volume 7, Issue 10. Calgary: The School of Public Policy University of Calgary, March 2014, p. 2.

http://policyschool.ucalgary.ca/sites/default/files/research/dobson-china.pdf (accessed June 5, 2014)
} 
FIGURE 1: HISTORICAL OIL SANDS M\&A TRANSACTIONS +,++

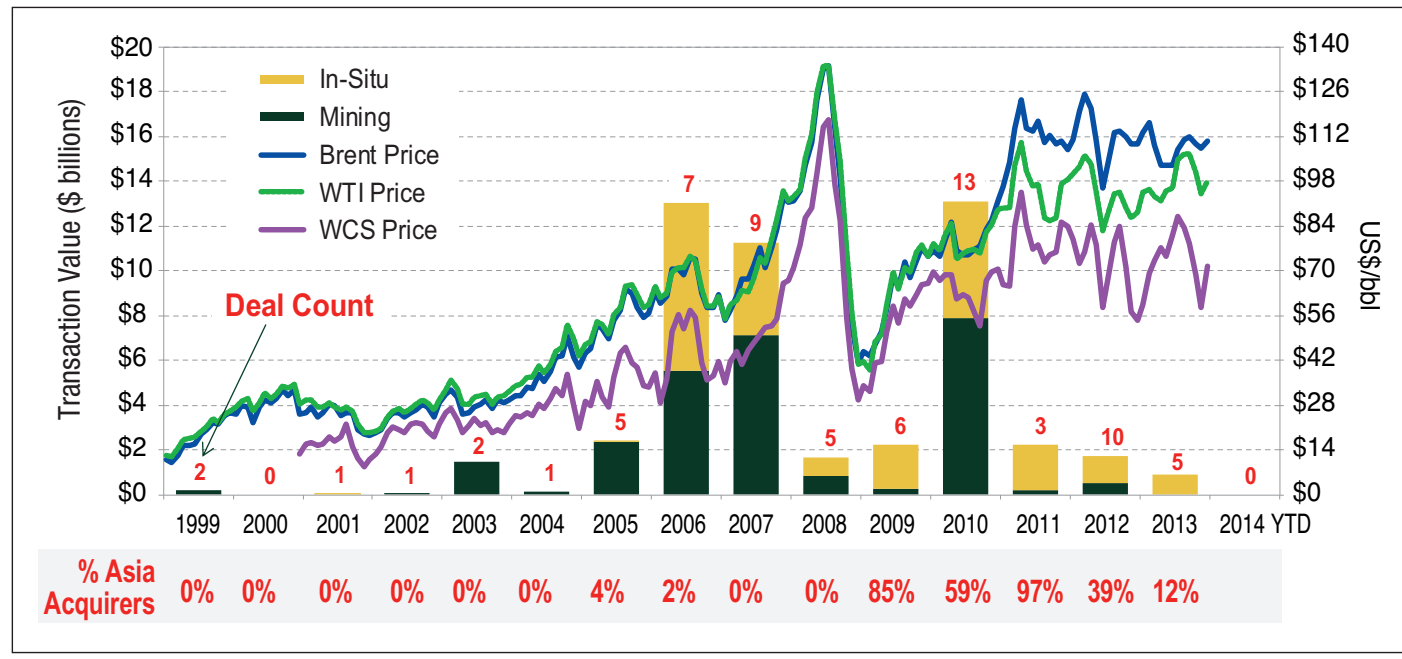

+ Source: TD Securities.

++ Does not include the Nexen acquisition, given less than 50 per cent of Nexen's resources and current production was weighted towards oil sands.

To summarize, the oil and gas industry is capital intensive and CERI forecasts that the oil sands projects will require $\$ 100$ billion in capital investment in the next five years. The Canadian economy relies on foreign investment for almost 20 per cent of assets, and this is higher at 35 per cent in the oil and gas sector. The extent of SOE investment in the Canadian oil and gas sector is relatively small but has, until recently, been growing rapidly. SOE investments have become increasingly important in world investment in resources generally, and in the energy sector in particular. The next section reviews the revised ICA with respect to SOE investment and undertakes empirically to estimate the impact of the changes on firms operating in the oil sands.

\section{Revised Guidelines for Oil Sands Investments by State-Owned Enterprises}

The revised guidelines for SOE investment announced on December 7, 2012 were specifically targeted towards the oil sands sector. Bill C-60, which was introduced on April 29, 2013 and has since received royal assent, was largely consistent with the initial policy announcement. The intent of the revised policy guidelines is to require controlling positions in the oil sands to pass a "net benefit" test.

The salient features of the revised guidelines and legislation are as follows:

- Broadens the definition of SOEs to an entity directly or indirectly controlled by a foreign government

- Triggers a "net benefit" review of SOE investments in the oil sands for transactions where the assets of the acquired business have a net book value of more than \$354 million. This threshold is expected to rise on an enterprise-value basis in annual stages for non-SOE investors, while remaining capped at book value for SOE investments

- Grants the industry minister the discretion to accept or deny any proposed deal

- Mandates that SOE acquisitions of control of oil sands assets must be on an "exceptional net benefit" basis only 
A careful reading of these guidelines reveals both more clarity in the rules and more uncertainty. The clarity comes from making it clear that controlling interests of oil sands firms by SOEs will not be permitted unless under exceptional circumstances reflecting Prime Minister Harper's statement that being open for business does not mean Canada is for sale to foreign governments. On the other hand, there is greater uncertainty in broadening the definition of what defines an SOE with respect to the Act, as well as what defines controlling interests. The new policy increases the discretionary power of the industry minister. Moreover, although the revised policy clearly focuses on controlling interests, as we discuss above, it is possible that the rule changes will have a broader impact on financing and investment in the oil sands. How these policy changes have affected the oil sands industry is the question we turn to now.

\section{ANALYSIS OF STOCK RETURNS OF THE OIL SANDS COMPANIES}

We empirically examine the impact on publicly traded firms operating in the oil sands by analysing the impact on their stock returns. In the empirical analysis, we control for other factors potentially affecting the stock returns of these firms. Following the standard market model approach, we control for the overall performance of the market, the risk-free rate of return and oil prices. We use the New York Stock Exchange (NYSE) index as the proxy for the overall performance of the market. The NYSE has the advantage over the Toronto Stock Exchange (TSX) of additional diversification outside of energy, along with cross-listings of Canadian firms. For oil prices, two crude streams are incorporated into the analysis: 1) Western Canadian Select (WCS) spot price, which is the benchmark heavy Canadian blend and most representative of the heavy oil price received by oil sands producers; and 2) West Texas Intermediate (WTI), which is the benchmark light sweet North American crude price. Both commodity prices and equity indices strengthened following the policy change. In light of this generally more supportive economic environment, the continued deterioration in the junior sector is striking. This provides prima facie evidence that the change in SOE investment policy may have disproportionately impacted the junior oil sands group.

Figures 2 and 3 show the equity indices, commodity and oil sands share prices are indexed to 100 at the time of the revised SOE policy guidelines. The senior/intermediate sector appears to have benefited from a more supportive economic environment, while the junior sector has continued to demonstrate declining share price returns. In Figure 2, the black line reveals the continued and steeper decline in share prices of an index of the junior oil sands firms postannouncement even as oil prices increase. The index of the share prices of intermediate/senior oil sands firms increases post-announcement. It looks like the share prices of the juniors and intermediates move together and reflect movements in the oil price prior to the announcement. Post-announcement, there is a break in the share prices of the junior index.

Figure 3 plots the index of the share prices of the juniors and intermediate/seniors against the market returns. Again, we see that prior to the announcement, the junior share index was strong up to mid-2012 and then experienced a correction from over 140 to 100 . The share price index was fairly stable until after December 2012, when the share index declined to below 50 - representing a 50 per cent decline in the index. Meanwhile, the oil sands intermediate/seniors continued to perform better than the juniors, and so did the market reflected by the NYSE and the TSX. 
FIGURE 2: OIL SANDS SHARE PRICE+ VERSUS OIL PRICE RETURN INDEXED TO 100 AT POLICY ANNOUNCEMENT

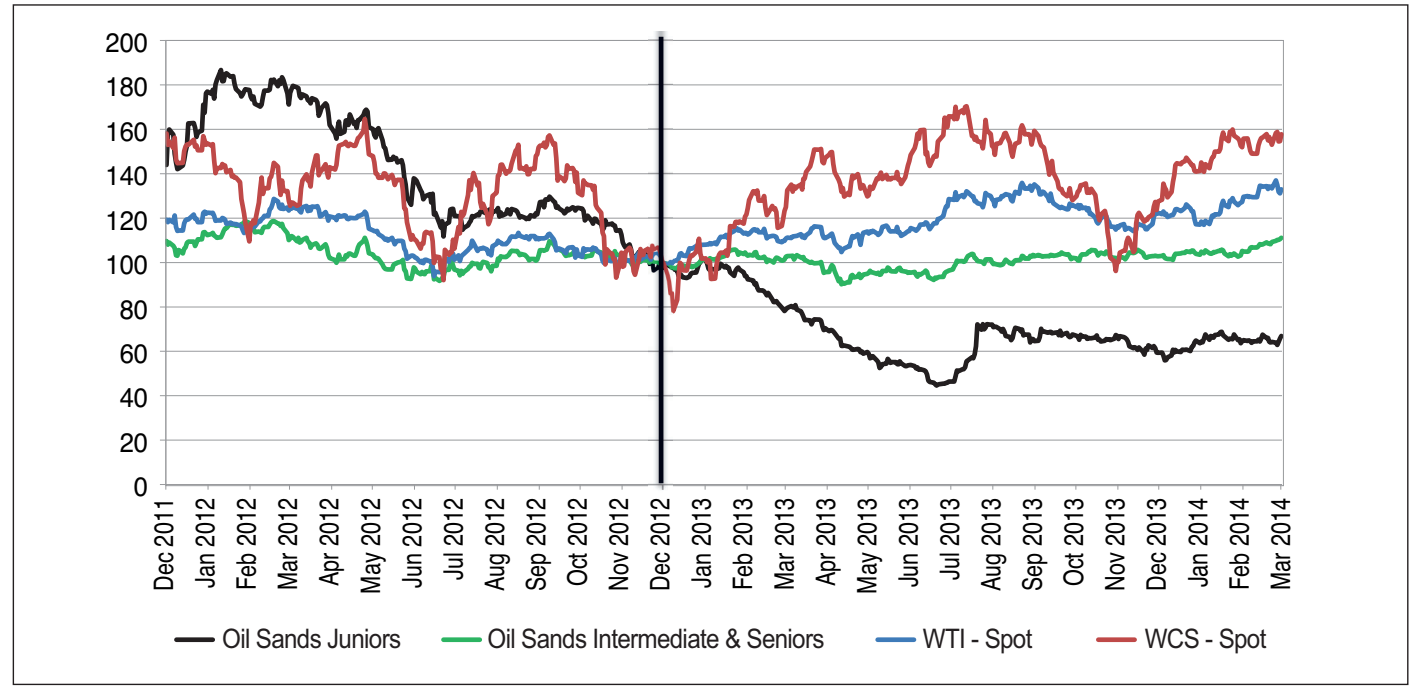

+ Oil Sands returns are equally weighted

The patterns in these share indices in Figures 2 and 3 reveal that the share prices of the junior oil sands firms declined dramatically in the first half of 2013. While the intermediate/senior oil sands firms fared better, their share prices did not increase in step with the oil prices or with the general market conditions. In the next section, we use regression analysis to control for the general market conditions and oil prices. We adopt an event study approach to explore the impact of the policy change on the stock market returns of the publicly traded oil sands firms.

\section{FIGURE 3: OIL SANDS SHARE PRICE+ VERSUS EQUITY INDEX RETURN INDEXED TO 100 AT POLICY ANNOUNCEMENT}

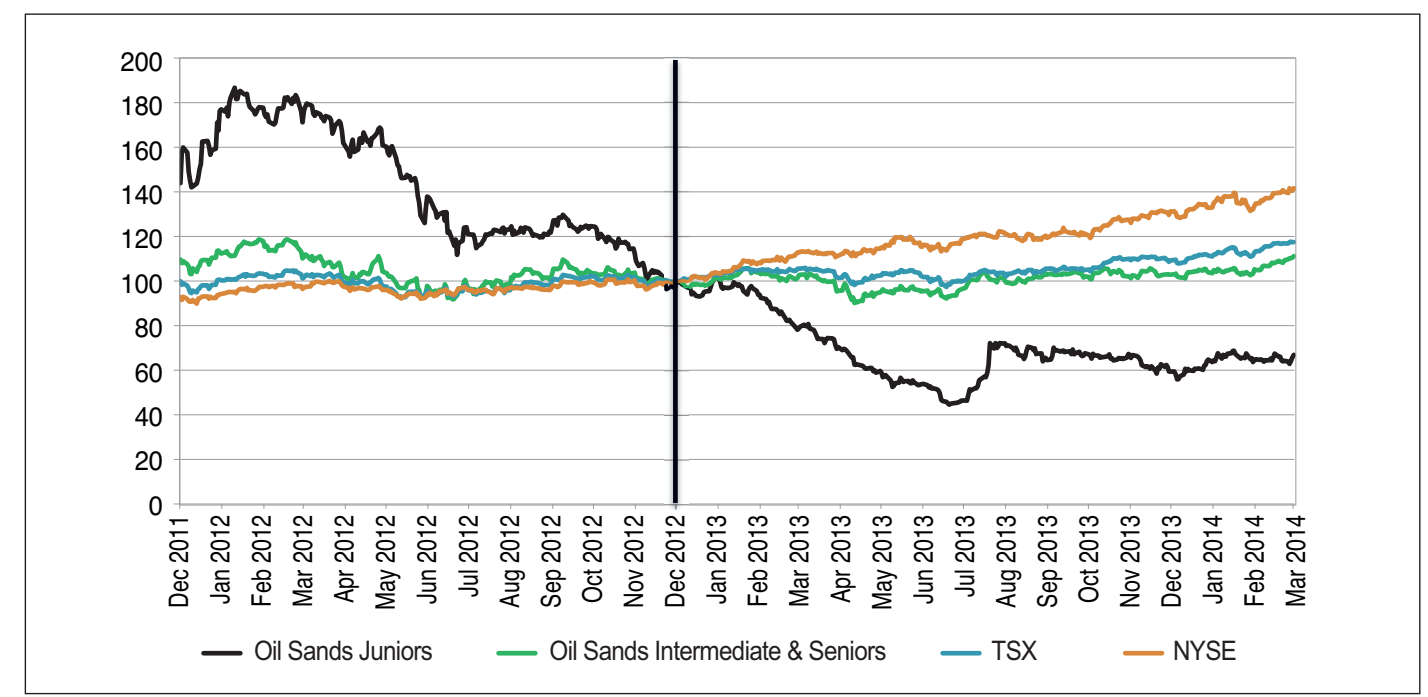

+ Oil Sands returns are equally weighted. 


\section{THE MODEL AND ECONOMETRIC METHODOLOGY}

Economists have long been interested in measuring the impact of policy changes on the value of firms, often employing an event study approach to do so. According to MacKinlay, the usefulness of this approach stems from the fact that, given rational markets, the impact of a policy will be reflected in security prices. ${ }^{14}$ The approach has been used effectively in a number of situations. ${ }^{15}$

We base our empirical analysis on the research conducted by Sadorsky, who showed that the stock prices of Canadian oil companies can be determined based on a market rate of return, such as the TSX and the price of oil. ${ }^{16}$ We adopt this into a standard event study analysis. We follow the event study literature and compute abnormal returns using the index of junior returns and the index of intermediate/senior returns described in the previous section. In particular, we estimate the following market model:

1. $\mathrm{R}_{\text {Junior Index } t}=-0.002+0.906 \times R M_{t}+0.275 \times$ Roil $_{t}$

$$
\begin{array}{lll}
\text { (s.e.) } \quad(0.0008) \quad(0.0829) \quad(0.0489)
\end{array}
$$

2. $\mathrm{R}_{\text {Intermediate/Senior Index } t}=-0.0003+0.790 \times R M_{t}+0.369 \times$ Roil $_{t}$

$$
\begin{array}{lll}
\text { (s.e.) } \quad(0.0004) & (0.044) & 0.0259
\end{array}
$$

3. $\mathrm{R}_{\text {All Firms Index } t}=-0.0012+0.845 \times R M_{t}+0.313 \times$ Roil $_{t}$

$$
\begin{array}{lll}
\text { (s.e. }) \quad(0.0006) \quad(0.058) \quad(0.034)
\end{array}
$$

where $R_{t}$ is the rate of return on the index of the daily share prices, $R M_{t}$ is the rate of return on the market (NYSE) and Roil $_{t}$ is the change in the oil price (WTI). In order to ensure the explanatory variables are exogenous, we use the NYSE instead of the TSX in our analysis. (The TSX and NYSE are highly correlated, and therefore, the results are similar when we use the TSX to conduct the analysis.) We also estimate the equation using different prices for oil. While we use the WTI in the results reported here, we also checked our analysis using WCS price and we get qualitatively similar results (not reported here).

14 Craig A. MacKinlay, "Event studies in economics and finance," Journal of Economic Literature 35 (1997): 13-39.

15 To see the approach used to exam the impact of U.S. presidential policies on U.S. firms, see Brian Knight, "Are policy platforms capitalized into equity prices? Evidence from the Bush/Gore 2000 Presidential Election," Journal of Public Economics 91 (2007): 389-409. For an examination of the impact of the 9/11 terrorist attacks on shipping companies, see Anthony C. Homan, "The Impact of 9/11 on Financial Risk, Volatility and Returns of Marine Firms," Maritime Economics \& Logistics 8 (2006) 8: 387-401. For an examination of the impact of changes in cigarette advertising regulations on tobacco companies, see Douglas J. Lamdin, "Event Studies of Regulation and New Results on the Effect of the Cigarette Advertising Ban," Journal of Regulatory Economics 16 (1999): 187-202. For an examination of the impact of the proposed Canada-US Free Trade Agreement on the stock prices of Canadian firms, see James A. Brander, "Election Polls, Free Trade, and the Stock Market: Evidence from the 1988 Canadian General Election," The Canadian Journal of Economics 24 (1991): 827-843; and Aileen J. Thompson, "Trade Liberalization, Comparative Advantage, and Scale Economies: Stock Market Evidence from Canada," Journal of International Economics 37 (1994): 1-27.

16 Peter Sadorsky, Peter, "Risk Factors in Stock returns of Canadian Oil and Gas companies," Energy Economics 23 (2001): 17-28. 
For the analysis, we follow the established event study procedure and estimated the equation separately for the junior index and the intermediate/senior index using daily data from July 28 , 2010 to December 7, 2012, which is the day the policy change was announced. We then use the parameter estimates from the regressions to calculate the abnormal return and cumulative abnormal return (CAR) for each index.

$$
\begin{aligned}
& \text { 4. } A R_{t}=R_{t}-\left(\hat{\alpha}+\widehat{\beta_{1}} R M_{t}+\widehat{\beta_{3}} \text { Roil }_{t}\right) \\
& \text { 5. } C A R=\sum A R_{t}
\end{aligned}
$$

where $\hat{\alpha}, \widehat{\beta_{1}}$, and $\widehat{\beta_{2}}$ are the estimated parameters from estimating equations 1,2 and 3 . We compute the abnormal returns separately for the juniors, the intermediate/seniors and all firms for the post-announcement period and compute the cumulative rate of return. We present the cumulative abnormal return graphically in Figure 4.

\section{FIGURE 4: CUMULATIVE ABNORMAL RETURNS POST POLICY ANNOUNCEMENT}

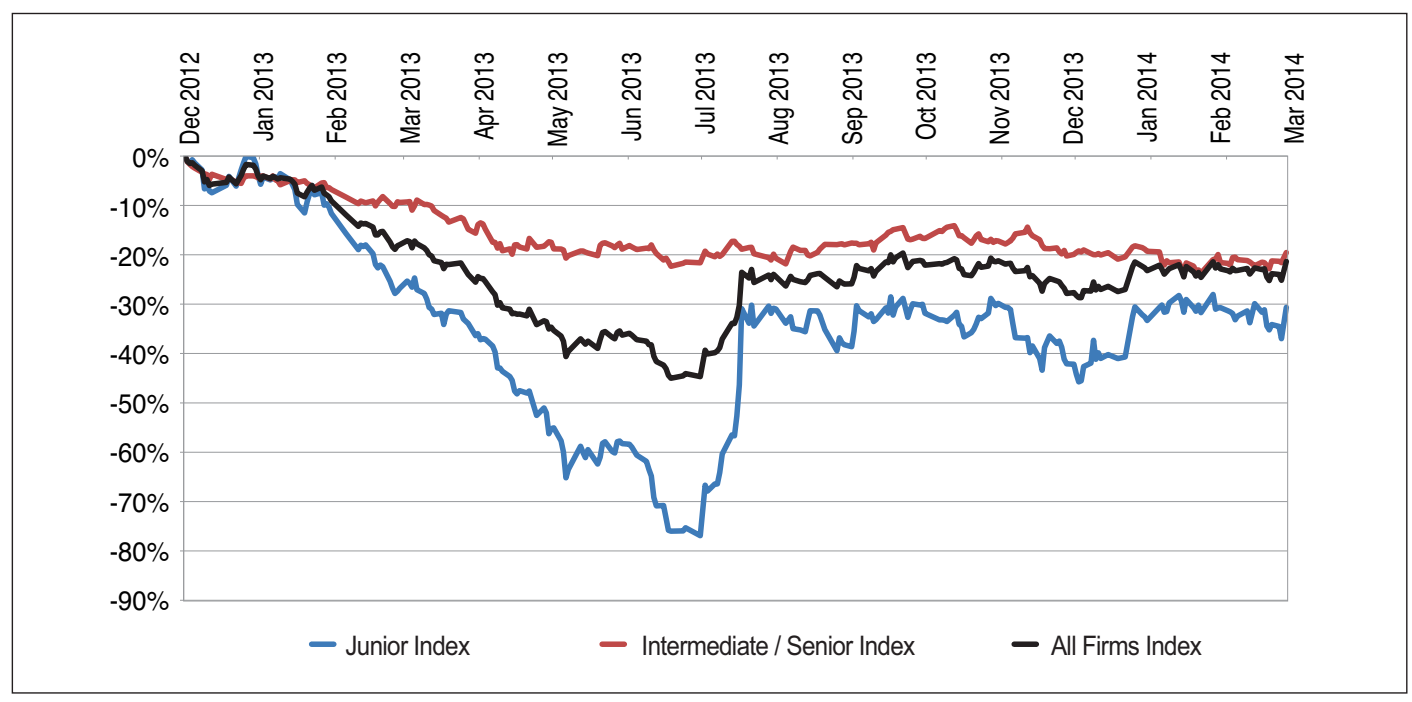

The aggregation of abnormal returns, summarized by the cumulative abnormal return over time, indicates that the policy change had a negative impact on oil sands share returns. In addition, Figure 4 demonstrates that the juniors were more severely impacted by the SOE policy change than the intermediate/senior oil sands group.

Over the month of July 2013, the junior index posted positive, and not negative, abnormal returns. This can be seen visually in Figure 4 by a sharp reduction in the negative cumulative abnormal returns. Examining the share trading data, we determine that this can be attributed to the equally weighted junior index significantly appreciating due to two large day-over-day company share returns in the sample: 1) Alberta Oil Sands (AOS) increased by 108 per cent between July 25 and July 26 as a direct result of the cancellation of its Clearwater oil sands leases and the associated expected compensation from the Alberta government); and 2) Connacher Oil and Gas (CLL) increased by 171 per cent over the July 16 to July 19 period (the reason in this case is not clear, but the share appreciation coincided with a sharp increase in CLL's trading volume). 
To the extent that these idiosyncratic firm effects are present, the standard event study approach may not adequately reflect the impact of the policy announcement. This may positively or negatively bias the magnitude of abnormal returns. ${ }^{17}$

\section{CONCLUDING REMARKS}

Using an event study framework, this paper examines the impact of the federal government's policy change towards acquisitions by SOEs on oil sands share returns. We find that the policy change has had a significant negative impact on the stock returns of oil sands companies. Further, negative returns attributable to the policy change are much more pronounced for the junior oil sands group, compared to the intermediate/senior oil sands firms. This is consistent with our hypothesis that juniors are more likely to be exposed to financing risk due to the fact they have limited internal cash flow to offset the requirement for external sources of financing. It is also consistent with the hypothesis that juniors have been adversely affected by the impact on JVs, an unintended consequence of a policy directed at particular sources of foreign ownership in the sector.

The findings of this paper indicate the federal government's policy change has resulted in the material destruction of shareholder wealth, both directly for those actively investing in the oil sands and indirectly through oil sands investment allocations in pension plans. However, the policy change also has broader implications for the real economy. According to Input-Output analysis by IHS- CERA, ${ }^{18}$ the oil sands accounted for five per cent of Canadian GDP, \$28 billion in government revenue and three per cent of all jobs in Canada in 2012, placing its economic contribution on par with Saskatchewan, Canada's fifth largest provincial economy. ${ }^{19}$ Failure to advance oil sands projects puts employment and social programs at risk. This is the reality of Canada being a small open economy with a capital-intensive resource sector. The welfare implications for Canadians of a policy that, to date, has contributed to a less healthy oil sands sector needs to be carefully considered by policy makers.

CERI estimates that the oil sands will require approximately $\$ 100$ billion in investment over the next five years. While foreign investment in the oil sands is not new, the increased presence of SOEs is. This raises a number of questions about what the sale of strategic natural resources means, particularly to China, the assumed target of the government's policy. Although the rise of the SOE as a key player in the global energy sector raises some important and legitimate concerns, the impact of the foreign investment restrictions on oil sands development must be considered. On this front, it is important to consider the dynamics of the global energy sector. The 2014 BP Outlook on World Energy predicts that global energy consumption will grow 41 per cent by 2035, with India and China accounting for half of that growth. Over that same period, BP predicts that the United States will produce 101 per cent of its energy needs.

\footnotetext{
17 We address this concern in our technical working paper in which we employ a fixed effects panel regression to account for firm-level effects to better isolate the impact of the policy change on oil sands share returns. We also conduct a number of robustness checks and get similar results.

18 IHS CERA, Oil Sands Economic Benefits.

19 Ibid.
} 
Moreover, the composition of the global oil industry has changed to one where SOEs dominate both reserves and production. Given these realities, is this the kind of principled policy stand Canada can afford to make? Is it feasible for Canada to exclude SOEs from the oil sands, given that SOEs control the bulk of the world's proven production and represent the largest players in the world's petroleum industry?

Our results indicate that the change in policy has had a negative effect, as measured by the impact on stock prices, on the industry, particularly the junior oil sands companies. We believe this will have negative consequences for the future development of the oil sands. A careful examination of the history of the oil sands reveals the negative consequences of government policy that restricts access to foreign capital, or that increases uncertainty in the sector. Research by Chastko and others demonstrates that uncertainty is the greatest deterrent to development in the industry. In the 1960s, 1970s and 1980s, both the federal and provincial governments insisted on retaining the right to alter the royalty and taxation provisions of oil sands projects on a case-by-case basis. It was not until the 1995 National Oil Sands Task Force adopted a universal standard that oil sands development really took off. The current policy directed at SOE investment in the oil sands has had a similar chilling effect on the industry and may impact development as similar policies did in the past.

Given the results from our analysis of this natural experiment, we hope that we have shed some light on the implications of the current policy - contributing to a lively, and hopefully more informed, policy debate that is currently underway.

\section{About the Authors}

Eugene Beaulieu is a Professor in the Department of Economics and the Director of the International Economics Program at The School of Public Policy at the University of Calgary. Eugene has been at the University of Calgary since 1997 after completing his Ph.D. at Columbia University in New York City. Eugene has worked as economist for the government of Kenya and the Bank of Canada and has been a visiting professor at Carleton University and the University of Western Australia. He has held numerous awards including the Petro-Canada Young Innovators Award, the Killam Resident Fellowship, and the Norman Robertson Fellowship at the International Trade Canada.

Matthew M. Saunders is a senior analyst with Laricina Energy, a privately held in situ oil sands company on the cusp of commercial scale development. Matthew focuses primarily on corporate planning, financial modeling, and working with senior management towards the company's financing efforts. Matthew has spent nearly eight years in the energy sector, previously with Western Oil Sands and Marathon Oil, and has chaired a working group for the Canadian Association of Petroleum Producers. Prior to entering the energy sector, he held a position as an economist with the Bank of Canada. Matthew holds a Master of Arts (Economics and Finance) from the University of Alberta and is a CFA charterholder. 


\title{
ABOUT THE SCHOOL OF PUBLIC POLICY
}

The School of Public Policy will become the flagship school of its kind in Canada by providing a practical, global and focused perspective on public policy analysis and practice in areas of energy and environmental policy, international policy and economic and social policy that is unique in Canada.

The mission of The School of Public Policy is to strengthen Canada's public service, institutions and economic performance for the betterment of our families, communities and country. We do this by:

- Building capacity in Government through the formal training of public servants in degree and non-degree programs, giving the people charged with making public policy work for Canada the hands-on expertise to represent our vital interests both here and abroad;

- Improving Public Policy Discourse outside Government through executive and strategic assessment programs, building a stronger understanding of what makes public policy work for those outside of the public sector and helps everyday Canadians make informed decisions on the politics that will shape their futures;

- Providing a Global Perspective on Public Policy Research through international collaborations, education, and community outreach programs, bringing global best practices to bear on Canadian public policy, resulting in decisions that benefit all people for the long term, not a few people for the short term.

\author{
The School of Public Policy \\ University of Calgary, Downtown Campus \\ 906 8th Avenue S.W., 5th Floor \\ Calgary, Alberta T2P $1 \mathrm{H} 9$ \\ Phone: 4032107100
}

\section{DISTRIBUTION}

Our publications are available online at www.policyschool.ca.

\section{DISCLAIMER}

The opinions expressed in these publications are the authors' alone and therefore do not necessarily reflect the opinions of the supporters, staff, or boards of The School of Public Policy.

\section{COPYRIGHT}

Copyright (C) 2014 by The School of Public Policy.

All rights reserved. No part of this publication may be reproduced in any manner whatsoever without written permission except in the case of brief passages quoted in critical articles and reviews.

\section{DATE OF ISSUE}

June 2014

\section{MEDIA INQUIRIES AND INFORMATION}

For media inquiries, please contact Morten Paulsen at 403-453-0062. Our web site, www.policyschool.ca, contains more information about The School's events, publications, and staff.

\section{DEVELOPMENT}

For information about contributing to The School of Public Policy, please contact Courtney Murphy by telephone at 403-210-7201 or by e-mail at cdmurphy@ucalgary.ca.

\section{ISSN}




\section{RECENT PUBLICATIONS BY THE SCHOOL OF PUBLIC POLICY}

FROM TRIAL TO TRIUMPH: HOW CANADA'S PAST FINANCIAL CRISES HELPED SHAPE A SUPERIOR REGULATORY SYSTEM

http://policyschool.ucalgary.ca/sites/default/files/research/savage-financeevol.pdf

Lawrie Savage | May 2014

THE FREE RIDE IS OVER: WHY CITIES, AND CITIZENS, MUST START PAYING FOR MUCH-NEEDED INFRASTRUCTURE

http://policyschool.ucalgary.ca/sites/default/files/bazelmintz-urban-growth.pdf

Philip Bazel and Jack Mintz | May 2014

ALBERTA CITIES AT THE CROSSROADS: URBAN DEVELOPMENT CHALLENGES AND OPPORTUNITIES IN HISTORICAL AND COMPARATIVE PERSPECTIVE http://policyschool.ucalgary.ca/sites/default/files/research/taylor-ab-cities-5.pdf

Anna Kramer, Marcy Burchfield and Zack Taylor | May 2014

ONTARIO'S EXPERIMENT WITH PRIMARY CARE REFORM

http://policyschool.ucalgary.ca/sites/default/files/ontario-health-care-reform.pdf

Gioia Buckley / Arthur Sweetman | May 2014

THE MIDDLE POWER AND THE MIDDLE KINGDOM: SECURING CANADA'S PLACE IN THE NEW CHINA-U.S. ECONOMIC AND STRATEGIC WORLD ORDER http://policyschool.ucalgary.ca/sites/default/files/dobson-china-communique.pdf

Wendy Dobson | April 2014

SAFETY IN NUMBERS: EVALUATING CANADIAN RAIL SAFETY DATA

http://policyschool.ucalgary.ca/sites/default/files/research/winter-rail-safety-communique.pdf

Jennifer Winter | April 2014

CHINA'S STATE-OWNED ENTERPRISES AND CANADA'S FDI POLICY

http://policyschool.ucalgary.ca/sites/default/files/research/dobson-china.pdf

Wendy Dobson | March 2014

THE TAMING OF THE SKEW: FACTS ON CANADA'S ENERGY TRADE

http://policyschool.ucalgary.ca/sites/default/files/research/tombe-can-energytrade.pdf

Trevor Tombe | March 2014

CANADA-KOREA FREE TRADE: A WATERSHED IN ECONOMIC INTEGRATION WITH ASIA

http://policyschool.ucalgary.ca/sites/default/files/research/canada-korea-trade.pdf

Eugene Beaulieu | March 2014

KEEPING THE GENIE IN THE BOTILE: GRADING THE REGULATION OF CANADIAN FINANCIAL INSTITUTIONS

http://policyschool.ucalgary.ca/sites/default/files/research/chant-financial-regulation-final.pdf

John Chant | March 2014

SIMULATED REPLACEMENT RATES FOR CPP REFORM OPTIONS

http://policyschool.ucalgary.ca/sites/default/files/research/milligan-cpp-options-final.pdf

Kevin Milligan and Tammy Schirle | March 2014

ABORIGINAL-CANADIANS AND ENERGY LITERACY: A SURVEY OF OPINIONS AND THOUGHTS ON ENERGY

http://policyschool.ucalgary.ca/sites/default/files/research/aboriginal-energy-literacy.pdf

Michal C. Moore, André Turcotte and Jennifer Winter | February 2014

THE RISE AND FALL OF SOCIAL ASSISTANCE USE IN CANADA, 1969-2012

http://policyschool.ucalgary.ca/sites/default/files/research/kneebone-white-social-assistance.pdf

Ron Kneebone and Katherine White | February 2014 